\title{
Cloning in livestock agriculture
}

\author{
D. N. Wells \\ Reproductive Technologies Group, AgResearch, PB 3123, Hamilton, New Zealand
}

\begin{abstract}
A tremendous amount is required of the oocyte cytoplasm to reprogramme a differentiated donor nucleus after somatic cell nuclear transfer so that it re-acquires a state of totipotency and can form a cloned individual. These reprogramming events must occur in a relatively short period after embryo reconstruction, quite unlike the situation during gametogenesis. It is remarkable that nuclear transfer can produce physiologically normal animals, but the process is highly prone to epigenetic errors. Aberrant patterns of gene expression are believed to contribute to the cumulative losses and abnormal phenotypes observed throughout development, from embryonic to adult stages. As a consequence, cloning efficiencies with current nuclear transfer technology are low and limit practical applications in farming. These applications depend upon the reliability with which nuclear transfer can reproduce specific genotypes and phenotypes in resulting offspring. Present animal welfare issues are a significant barrier for acceptance of nuclear transfer in agriculture. Any long lasting effects from cloning, as revealed in some mouse studies, need to be comprehensively evaluated in cloned livestock. The safety of food products derived from clones also needs to be thoroughly evaluated. The current indication that the sexually derived offspring of nuclear transfer clones are normal provides confidence for the first applications of the technology in agriculture, namely the generation of cloned, genetically elite animals for subsequent breeding. Future improvements in cloning will come from both technical advances and a greater fundamental understanding of the molecular mechanisms of reprogramming with an aim to control this process better. Increased efficiencies should improve the acceptability and utility of cloning technology.
\end{abstract}

\section{Methods of cloning mammals}

There are four main methods for producing genetically identical mammals:

- Individual separation of embryonic blastomeres up to the four-cell stage

- Embryo bisection at the morula or blastocyst stages

- Tetraploid embryo complementation

- Nuclear transfer (or nuclear cloning) 
The first two cloning methods rely on the inherent cellular totipotency of very early embryonic cells which, therefore, Jimits the number of viable embryos and offspring that can be obtained, although embryo splitting has been applied to commercial multiple ovulation and embryo transfer (MOET) programmes aimed at multiplying valuable genotypes (Wells et al., 1990). The animals produced from founder embryos using these methods are true clones, in that they share identical mitochondrial $(\mathrm{mt})$ and genomic DNA and the embryonic cells generate the entire conceptus. The third cloning method has been accomplished only in the mouse whereby pluripotent embryonic stem (ES) cells combined with tetraploid host embryos result in offspring comprised solely from the differentiated derivatives of the original ES cells and with the tetraploid cells contributing to the extraembryonic lineages developing into the placenta. In contrast to the above methods, in which it is the inherent cellular totipotency that yields cloned offspring, the nuclear transfer (NT) methodology restores the developmental totipotency of the nucleus. Of the cloning methods presently available, NT has the greatest potential for animal agriculture and has the opportunity to produce genomic copies of selected adult animals. Therefore, NT forms the focus of this review with emphasis on common farmed livestock species, particularly cattle and sheep. Relevant data from mouse models that improve our understanding of the biology and consequences of nuclear cloning will also be discussed.

\section{Nuclear transfer (or nuclear cloning)}

Nuclear transfer is a multi-step process (outlined below) that essentially generates an entire organism from the nuclear DNA of a single donor cell. The basic methodology was first developed in amphibians in the 1950s and was used to investigate nuclear totipotency in differentiated cell populations. In livestock species, undifferentiated embryonic blastomeres were first used successfully in sheep (Willadsen, 1986), cattle (Prather et al., 1987) and pigs (Prather et al., 1989). Embryonic NT has been extended in mice to include the use of other undifferentiated types of cell, including ES cells derived from the inner cell mass (ICM) of blastocysts (Wakayama et al., 1999). The use of more differentiated types of cell obtained from embryos (Campbell et al., 1996), fetuses or most significantly adult animals (Wilmut et al., 1997) overturned a dogma in biology concerning nuclear totipotency and has consequently opened new avenues in fundamental and applied research. This technique has been termed somatic cell NT to distinguish it from NT with undifferentiated embryonic cells.

Animals obtained by NT are not strictly true clones. These animals might for instance possess: (i) different mtDNA derived from the recipient oocyte; (ii) point mutations or other chromosomal rearrangements in the genomic DNA of individual donor cells; (ii) alternative patterns of X-chromosome inactivation in females; (iv) various other epigenetic alterations arising from in vitro culture (of the donor cells or reconstructed embryos) or perturbations from the NT process; and (v) environmental influences from the oocyte cytoplasm, maternal uterus in the surrogate female and during the post-natal period. All of these factors contribute to potential variations in phenotype (and genotype in some cases) within a clonal family (a set of nuclear clones derived from the same source of donor cells) and deviations from the original founder animal.

\section{Current efficiency of somatic cell nuclear transfer}

Overall, the current efficiency of NT with somatic cells is low. Specifically at AgResearch, the proportion of reconstructed one-cell bovine embryos that develop to blastocysts of transferable quality after culture for 7 days, from a variety of cell lines $(40 \%)$, is comparable to that after in vitro embryo production (IVP; that is, in vitro matured, fertilized and cultured) with 


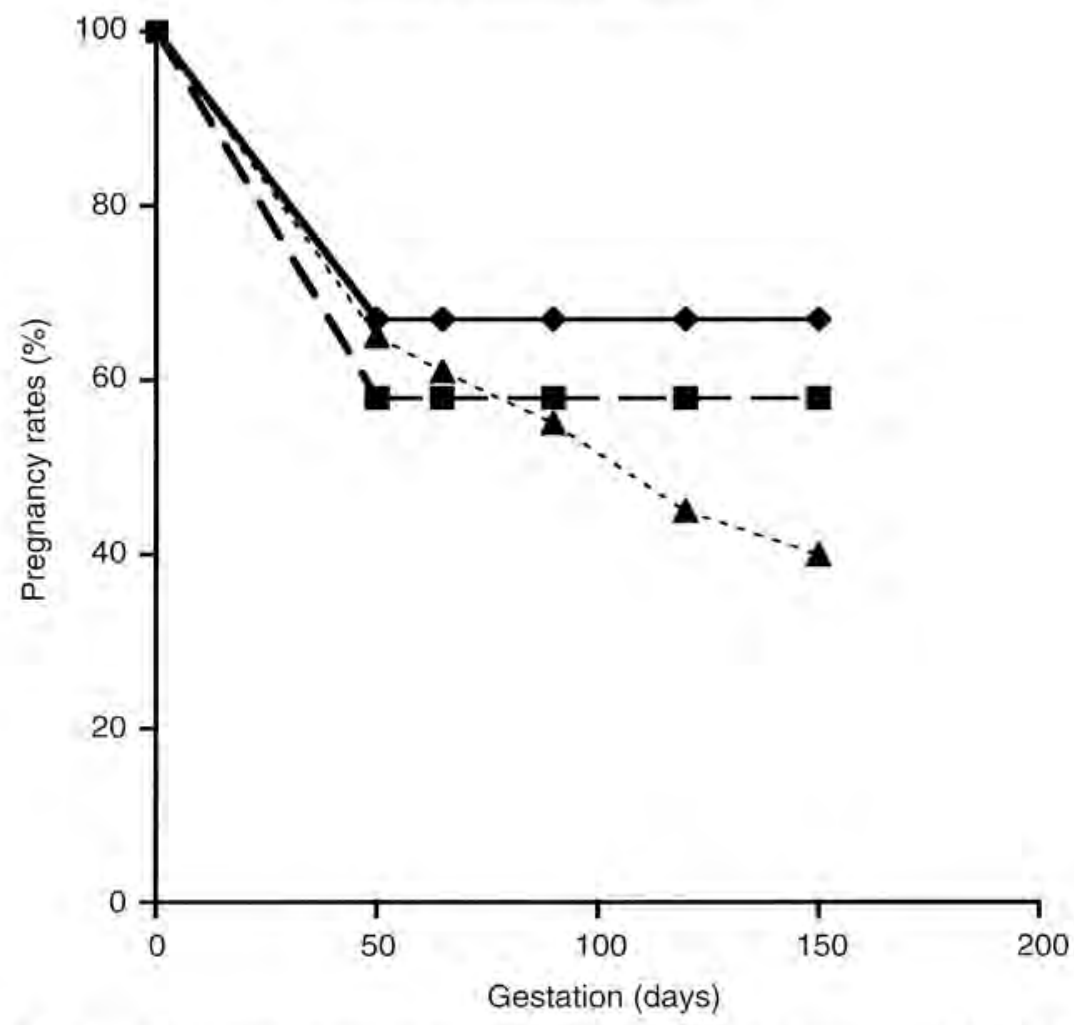

Fig. 1. Pregnancies involving cloned embryos are not maintained throughout gestation. Despite similar rates of pregnancy establishment with nuclear transfer bovine embryos (A) on day 50, there were continual losses throughout gestation unlike the situation for embryos produced in vitro (-) and artificially inseminated $(\bullet$ controls. A major cause of these pregnancy failures is abnormal development of the placenta in the clones. Single nuclear transfer and in vitro produced embryos were transferred to each recipient in this experiment which was terminated at day 150 (R. Lee and D. Wells, unpublished).

oocytes obtained from an abattoir. However, only $15 \%$ of cloned embryos transferred into synchronized recipient cows result in viable calves at weaning. This finding compares to $45 \%$ embryo survival with IVP. Although initial pregnancy rates in cattle after the transfer of single NT and IVP embryos are both similar to artificial insemination (Al), there is continual loss thereafter with the clones (Fig. 1). Moreover, peri-natal and post-natal mortality rates with cloned offspring are greater than normally expected and there are concerns regarding their long-term health into adulthood (see below).

From an animal welfare perspective, in addition to farmer and consumer acceptance of the technology, these losses must be solved before any large-scale cloning opportunities are practicable or tolerated. Ideally, cloning must have pregnancy rates comparable to those achieved with sexual reproduction, principally AI or MOET which are $55-60 \%$ (Kruip and den Daas, 1997). However, it is important to remember that somatic cell NT can be effective in producing what appear to be physiologically normal animals. This finding provides encouragement for eventually resolving technical issues and elucidating the molecular mechanisms responsible for effecting complete epigenetic reprogramming. 


\section{Nuclear transfer manipulations}

\section{Mechanics of embryo reconstruction}

The standard methodology involves the use of sharp, bevelled micropipettes mounted on micromanipulators to perform enucleation and cell injection steps. Alternative methods to remove the metaphase plate from oocytes either chemically (Karnikova et al., 1998) or by centrifugation (Tatham et al., 1995) have been developed. Together with methods to reconstruct embryos after enzymatic removal of the zona pellucida (Vajta et al., 2001), these systems increase laboratory throughput, require less skill and technical training, and reduce costs. These aspects are important as they enable better standardization of laboratory procedures to reduce operator effects. Simplified procedures are also necessary for potential commercialization and would involve more (semi-) automated technology, such as perfusion systems for in vitro culture and microfluid systems to reduce the manual manipulation of embryos (Beebe et al., 2002). Together these procedures may lessen the risks of perturbing embryonic development.

\section{Cytoplasts}

The selection and preparation of competent cytoplasts are vital, as factors present within the oocyte cytoplasm are required to remodel donor chromatin, reprogramme the pattern of gene expression (Rideout et al., 2001) and enable embryo activation (Machaty and Prather, 1998). The use of oocytes at metaphase II of meiosis is favoured. For both large-scale research and commercial applications, only in vitro matured oocytes obtained from ovaries from abattoirs are practical in farm animals. However, this introduces considerable biological variation making it difficult to standardize experiments.

The source of recipient oocytes can potentially affect the outcome of NT. Incompatible nuclear-cytoplasmic interactions can adversely affect development (Reik et al., 1993; Roemer et al., 1997). Sheep breed (Dinnyes et al., 2002) and maternal lineage of cows (Bruggerhoff et al,, 2002) can both significantly influence the competency of cytoplasts to develop after NT. Cloned animals produced via cell fusion show a low level of heteroplasmy in which mtDNA is mainly from the recipient oocyte with a small contribution from the donor cell (Steinborn et al., 2000). The consequence of this on subsequent development is not fully appreciated. Some NT reconstruction methods that fuse the donor cell with at least two cytoplasts (probably obtained from different females with different mtDNA) (Peura et al., 1998) potentially increase the degree of heteroplasmy. The source of the oocyte could potentially alter the phenotype of the clones as maternal inheritance significantly influences agricultural production traits including milk production, reproduction, health (Schutz et al., 1994) and carcass composition (Mannen et al., 1998). Thus, there are opportunities to use mtDNA polymorphisms to identify ova from females with advantageous cytoplasm for NT or production. Given the expense of routine ovum pick-up to provide cytoplasts for NT there would be advantages in the future of being able to harvest oocytes in vitro repeatedly from primordial oocyte culture. Theoretically, maternal lineage and mtDNA heteroplasmy are of no consequence in the production of cloned males from progeny-tested sires for breeding. For germline transmission, the clones need only to be faithful genomic copies of the original size and are not confounded by oocyte source, as sperm mtDNA is selectively destroyed after fertilization.

\section{Donor cells}

The choice of donor cells used for NT has been reviewed extensively by Oback and Wells (2002). The cells can come from a wide variety of tissues ex vivo, after variable durations of 
in vitro culture or after genetic manipulation. Only a fraction of all types of cell have been used for NT and in general they have been poorly characterized. Many fetal cell lines are heterogeneous and clonally derived sub-lines have different cloning efficiencies. The differentiation of cells is associated with the assembly of specialized forms of repressive chromatin (Kikyo and Wolffe, 2000) and sometimes with DNA rearrangements that may reduce developmental totipotency as with post-mitotic differentiated neural cells (Yamazaki et al., 2001), or require modifications to the cloning procedure, as with mature lymphocytes (Hochedlinger and Jaenisch, 2002). Less differentiated multipotent or pluripotent cells are potentially easier to reprogramme, as observed in mice in which the development of transferred cloned embryos into live fetuses at term tends to be greater with hybrid ES cells (8-21\%) (Wakayama et al., 1999; Rideout et al., 2000; Eggan et al., 2001) in comparison with fetal (1.8-3.7\%) and adult cells (0.5-3.1\%; Wakayama and Yanagimachi, 2001a). A similar trend has been observed in cattle, in which the proportion of transferred cloned embryos that develop into live calves from day 6 blastomeres, and fetal and adult fibroblasts was 28,13 and $5 \%$, respectively (Heyman et al., 2002a). This effect may be related to the state of differentiation or age of the animal.

The practical considerations of a non-invasive tissue biopsy from live prize animals limit the types of cell potentially available for NT. Dermal skin fibroblasts have been commonly used. Mammalian cells in culture are prone to accumulate genetic mutations, chromosomal errors and epigenetic anomalies, such as alteration of methylation status and loss of imprinting. Nevertheless, bovine skin fibroblasts have maintained a stable karyotype in long-term culture and have been successfully used for NT after 15 passages (Kubota et al., 2000). Variation in the ability to produce cloned animals from cell lines isolated from a single biopsy, or from the same individual at different ages, point to the vagaries of in vitro culture conditions (Renard et al., 2002). There is little indication of an effect of sex per se on cloning efficiencies; however, genotypic differences have been observed in cattle (Heyman et al., 2002b) (however, this may simply reflect differences between individual cell lines) and mice. Compared with inbred strains, heterozygous $F_{\uparrow}$ mouse strains result in greater development of cloned embryos to term and greater post-natal survival into adulthood with both ES cells (Wakayama et al., 1999; Rideout et al., 2000; Eggan et al., 2001) and cumulus cells (Wakayama and Yanagimachi, 2001a).

Considerable effort and debate has focused on the relative importance of the donor cell cycle phase on NT. Compatibility between the recipient cytoplast and donor nucleus is necessary to maintain normal ploidy. Certain combinations and specific protocols achieve this, with some influence of species affecting outcome. For somatic cell NT at least, preactivated cytoplasts result in poorer development compared with non-activated metaphase II cytoplasm (Wakayama and Yanagimachi, 2001b; Heyman etal., 2002b). However, donor cells in S-phase are incompatible with non-activated cytoplasm as a result of DNA fragmentation upon exposure to maturation promoting factor. Among cell cycle combinations that are compatible in maintaining ploidy, there is as yet little compelling evidence to indicate that any specific phase between $\mathrm{G} 2-\mathrm{M}-\mathrm{GO}-\mathrm{G} 1$ of the donor cell cycle is a superior epigenetic state for reprogramming (Oback and Wells, 2002).

It may be necessary to pretreat donor cells or nuclei to modify chromatin states so that they are more amenable to reprogramming. Initial attempts, including serum starvation (Campbell et al., 1996), which decreases DNA methylation and alters the expression of certain genes including those that are imprinted (Hayashida et al, 1997), 5-azacytidine to induce hypomethylation (Jones et al., 2001) and protease treatment (Renard et al., 2002), have all been rather broad spectrum and with little evidence of significant advantages. 


\section{Fusion and activation}

Methods to introduce the donor nucleus into the cytoplast in livestock species typically involve electrical cell fusion. The small diameter of somatic cells poses technical difficulties with alignment in the fusion chamber. Direct nucleus injection procedures, favoured in mice (Wakayama et al., 1998), have been adapted and used successfully in pigs (Onishi et al., 2000), goats (Zou et al, 2001) and cattle (Heyman et al., 2002b). However, in cattle, although similar rates of development in vitro have been achieved there are initial indications of poorer development in vivo. A potential advantage of nucleus injection techniques is that they might reduce $\mathrm{mtDNA}$ heteroplasmy.

After reconstruction, it had been considered preferable to delay activation to prolong the period during which the donor chromatin is exposed to factors present in the oocyte cytoplasm. However, the omission of cytoskeletal inhibitors during activation has enabled simultaneous fusion and activation strategies to result in similar cloning efficiencies in mice (Wakayama and Yanagimachi, 2001b). The quality of the artificial activation signal to initiate repetitive intracellular calcium oscillations of the correct amplitude, frequency and duration to simulate sperm activation is vital in promoting embryo development (Ozil and Huneau, 2001).

\section{Modifications of the basic nuclear transfer procedure}

Other possible methods to prolong the period of exposure of donor nuclei to cytoplasmic reprogramming factors include nuclear recycling and serial NT. Unfortunately, recycling bovine embryonic blastomeres from disaggregated morulae produced in successive rounds of NT actually decreased developmental potential in vitro and in vivo with each successive generation (Peura et al., 2001). There is an apparent developmental advantage with the use of enucleated zygotes in a two-step serial NT procedure, possibly arising from using spermactivated cytoplasm (Polejaeva et al., 2000) or the presence of early sperm-derived transcripts (Kono, 1997). Furthermore, serial NT appears to reduce some abnormalities in cloned mouse pregnancies compared with conventional single NT (Ono et al., 2001). The complementation of murine ES cells with tetraploid host embryos results in placental masses and fetal weights similar to those of in vilro cultured controls and significantly less than with NT clones (Eggan et al., 2001). This methodology has been used as an intermediate step in generating cloned mice from somatic cells. Somatic cell NT is first used to generate cloned blastocysts from which ES cells are derived and subsequently injected into tetraploid blastocysts and allowed to develop to term (Hochedlinger and Jaenisch, 2002). Although livestock ES cells are presently unavailable, the ICMs from cloned blastocysts could be used alternatively in a similar approach.

\section{Embryo culture}

Culture conditions can influence embryo development rates and expression of developmentally important genes (Niemann et al., 2002). Serum present during in vitro culture of sheep embryos results in larger lambs (Thompson et al., 1995). The large offspring syndrome is typified by other developmental perturbations (Young et al., 1998) and is associated with reduced methylation and expression of the imprinted IGF2R gene (Young et al., 2001). The subjective quality of cloned blastocysts bears little correlation with their viability in vivo and differential staining of cloned bovine blastocysts shows relatively fewer trophectodermal cells compared with IVP embryos (Kang et al., 2002). An advance in embryo culture systems 
has been the use of sequential media to drive embryos along appropriate metabolic paths (Thompson et al., 2000). This procedure has improved development of cattle NT embryos at AgResearch. Chung et al. (2002) reported that specific culture conditions are required for mouse NT embryos as they experience a high demand for glucose shortly after reconstruction which, if met, results in improved blastocyst development. This finding may prompt the use of triphasic media during the in vitro culture period.

\section{Epigenetic anomalies}

For normal embryogenesis to occur after NT, it is generally accepted that the donor nucleus must be reprogrammed to a state comparable to that in a zygote to allow for the correct pattern of subsequent gene expression. This reprogramming must occur in a short timeframe, in a different cellular context compared with normal development and is prone to errors. An increasing number of studies have reported deviations in epigenetic reprogramming. The pattern of mortality and clone phenotypes observed presumably reflects the inappropriate expression of various genes, the harmful effects of which are exerted at different stages of development. Aberrations that occur early in embryonic or fetal development may impair health in adulthood.

It is hypothesized that alterations in gene expression after NT are caused by epigenetic errors primarily in the patterns of DNA methylation and chromatin organization. Frequently, the donor cell pattern of DNA methylation is maintained during preimplantation development indicating incomplete or lack of reprogramming (Kang et al., 2001a). However, demethylation across the genome was enhanced when donor nuclei were fused to nonenucleated oocytes by as yet unknown mechanisms (Kang et al, 2001b). Moreover, cloned bovine blastocysts were differentially demethylated depending upon the genomic sequence and cell lineage analysed (Kang et al., 2002). Satellite sequences remained methylated in the trophectoderm, whereas in the ICM they were demethylated. The occurrence of abnormal DNA methylation in the trophectoderm is intriguing and is consistent with the observations of abnormal gene expression in placental tissue (Inoue et al., 2002) and resulting abnormal placentation in cloned conceptuses (Hill et al., 2000).

Highly variable aberrations in genomic methylation in cloned mice at full term have also been observed (Ohgane et al., 2001). This finding, along with stochastic variations in the expression of imprinted genes in adult mice cloned from ES cells, indicates that mammalian development may be tolerant to minor epigenetic aberrations, at least up to a threshold (Humpherys et al., 2001). Obviously, in extreme situations these could be lethal or result in a pathological condition.

The dysregulation of imprinted genes may be due to faulty reprogramming or pre-existing epigenetic errors in donor cells, or both. ES cells have an inherently unstable epigenotype and errors in the maintenance of imprinting marks during the life of the donor cell cannot be repaired in nuclear clones and may lead to unbalanced imprinting and growth abnormalities (Humpherys et al., 2001). However, some somatic cells may be more completely reprogrammed, as observed in those phenotypically normal mouse fetuses that do not have imprinting errors, although faulty gene expression was still detected in their overgrown placentae (Inoue et al., 2002). At least some genomic imprints established during gametogenesis are maintained after NT. AgResearch results show that despite developmental retardation of preimplantation sheep clones, in which the allantoic sacs were significantly smaller, they have similar allelic expression patterns of IGF2 to those of IVP controls. The epigenetic modifications for the IGF2 gene in the donor cells were effectively erased and re-established after NT, as observed by the paternal expression of IGF2 in ovine fetal donor cells switching to 
biallelic expression by day 14 and back to the correct monoallelic expression by day 21 (T. Xiang and R. Lee, unpublished).

A measure of correct reprogramming includes the reactivation of the inactive $X$ chromosome in female somatic cells after NT (Eggan et al., 2000). However, there may be faulty inactivation in subsequent embryogenesis. Normally, the paternal $\mathrm{X}$ chromosome is preferentially inactivated in the placentae of mice and cattle. However, after NT, it is the inactive $X$ chromosome in the somatic donor cell (which may be either maternally or paternally inherited) that is preferentially inactivated in the placentae of cloned mice (Eggan et al., 2000) and probably in cattle (Xue et al., 2002). In cloned calves that died at birth, X chromosome inactivation in the placenta was random unlike in surviving clones (Xue et $a_{+}, 2002$ ). In the blood and skin of cloned calves there was random, monoallelic X chromosome expression, as normal.

\section{Markers for reprogramming}

The ultimate marker for complete reprogramming is the production of normal cloned offspring that survive into adulthood. This is difficult to assess in animal species that have long gestational periods and lifespans. Definitive molecular markers that correlate well with normal development are needed. This would enable more rapid evaluation of new NT treatments by analysing whole embryos, or ideally a biopsy, to assess potential viability after embryo transfer. A potential problem with a biopsy is that the embryo may be mosaic whereby different cells within the embryo may be reprogrammed either completely, partially or not at all (Boiani et al., 2002; Kang et al., 2002). Therefore, it may be necessary to bisect embryos to obtain a more representative sample. Microarrays could be used to analyse many genes in a single embryo or biopsy (Niemann et al., 2002; Renard et al., 2002). However, mRNA phenotyping determines gene expression only at the specific stage of development assessed. Nevertheless, these expression patterns may correlate with subsequent outcomes; for example, the high, early expression of interferon $\tau$ was associated with an NT treatment resulting in low viability in vivo (Wrenzycki et al., 2001). Oct-4 has been identified as a potential marker for reprogramming in the mouse in which expression was not localized to the ICM as normal in most cloned blastocysts (Boiani et al., 2002). Identifying in situ localization of mRNA or protein is important, as expression must occur in the correct tissues, in addition to the correct stage of development and correct dosage. This is further exemplified by Oct-4 in which a $30 \%$ under- or overexpression alters the cell differentiation pathway (Niwa et al., 2000). Oct-4 may not be a useful marker in other species, as expression also occurs in the trophectoderm of bovine and pig blastocysts (Kirchhof et al., 2000). However, a potential reprogramming marker in cattle may be fibroblast growth factor 4, which is transcriptionally regulated by Oct-4 (Ambrosetti et al., 2000), required for development at early implantation in the mouse and aberrantly expressed by most bovine NT blastocysts (Daniels et al., 2000).

\section{Placental abnormalities}

Failure of the placenta to develop and function correctly is a common feature among clones. Most early pregnancy failures before placentome formation are attributed to an inadequate transition from yolk sac to allantoic derived nutrition, with poor allantoic vascularization in sheep (De Sousa et al., 2001). Typically, in cattle, $50-70 \%$ of pregnancies at day 50 are lost throughout the remainder of gestation and up to term (Wells et al., 1999; Hill et al., 2000; Lanza et al., 2001). This finding is in marked contrast to only $0-5 \%$ loss with Al during the same 
period. The losses with the clones occur despite the presence of abundant fetal cotyledonary tissue at day 50. However, this tissue apparently fails to interact with the maternal caruncles subsequently to form functional placentomes. In extreme cases, placentomes are entirely absent by day 70 . The development of the fetus becomes retarded and, shortly thereafter, these pregnancies fail. More commonly, cloned placentae have only half the normal number of placentomes which display compensatory overgrowth and are oedematous (Hill et al., 1999, 2000; R. Lee and D. Wells, unpublished).

Of particular concern are the losses in the second two-thirds of gestation, especially the occurrence of hydroallantois. Twenty-five per cent of cows pregnant at day 120 of gestation commonly develop clinical hydrops (D. Wells, unpublished). The range is variable $(0-40 \%)$ and the incidence is possibly dependent upon the cell line. Cases are typically sufficiently severe to render the calves non-viable and on welfare grounds, to reduce the risk of mortality to the recipient cow, our standard practice is electively to terminate the hydrops pregnancy.

This is an unsatisfactory procedure and work is underway to identify non-viable pregnancies much earlier in development to lessen the welfare burden. Ideally, a panel of molecular reprogramming markers with a high correlation with normal development in vivo would enable viable embryos to be selected before transfer into recipients. Alternatively, abnormal pregnancy development could be determined by measuring specific components present in maternal serum and early detection would allow early elective abortion. Pregnancy-specific protein b produced by the binucleate cells of the trophoblast was transiently higher at day 35 in conceptuses that failed to develop to day 90 (Hill et al., 2000). Similarly, pregnancy serum protein 60 concentration was high for the first 4 months of gestation in pregnancies that became pathological (Heyman et al., 2002a). Monitoring would be complemented by detailed ultrasonography (Hill et al., 2000; Heyman et al., 2002a). In pigs, there is the added complication of the requirement for four to five viable embryos to maintain pregnancy. In addition to hormone therapy, options include the co-transfer of parthenogenetic embryos together with NT embryos (De Sousa et al., 2002).

\section{Difficulties in parturition}

Intervention is often deemed necessary to deliver cloned offspring, as the duration of gestation in NT pregnancies is typically prolonged. Newborn cloned calves display functional adrenal glands, so this extended gestation may be due to failure of the placentae to respond to fetal cortisol near term or to a lack of ACTH release from the fetus (Chavatte-Palmer et al., 2002). Oversized cloned offspring add to the birth complications. They are larger than IVP, AI or naturally mated controls (Wilson et al, 1995) and somatic cloned calves are apparently heavier than embryonic clones (Heyman et al., 2002a).

At AgResearch, the occurrence of prolonged gestation and the risk of dystocia initially prompted the delivery of clones by elective Caesarean section after a brief exposure to exogenous corticosteroids (Wells et al., 1999). Recognizing the welfare issues and the intensive peri-natal veterinary care often required we have modified our calving management system. The aim of this system is to have a planned vaginal delivery (with manual traction if necessary), using an alternative corticosteroid therapy to aid fetal maturation, especially of lungs, and to induce parturition completely a week before expected full-term gestation. This protocol has reduced the incidence of Caesarean section to $5 \%$ and most of the cloned calves are reared on their recipient dams. Although not completely natural, this approach towards delivering cloned calves in a controlled manner is feasible and acceptable on the farm. 


\section{Post-natal viability of cloned offspring}

The viability of cloned offspring at delivery and to the age of weaning is lower than that of normal offspring and this is despite the greater veterinary care that cloned offspring receive. Data from our group show that $86 \%$ of cloned calves are alive after the first $2 \mathrm{~h}$ of delivery. Most calves die during this period because of respiratory distress. Clones have altered neonatal metabolism and physiology possibly due to placental abnormalities, and take time to adjust to normality (Garry et al., 1996; Chavatte-Palmer et al., 2002). We find that the incidence of respiratory distress in sheep is greater than in cattle and have had only limited success with oxygen therapy or the administration of respiratory stimulants.

Additional losses throughout the post-natal period are mostly due to abnormalities of the cardiovascular, skeletal and central nervous systems, umbilical and lung infections, along with digestive and kidney disorders (Hill et al., 1999; Renard et al., 2002; D. Wells, personal observations). Hydronephrosis is particularly common in sheep (Wells et al., 1997) and correspondingly high serum concentrations of urea are found in some surviving clones (Wells et al., 1998a).

The proportion of cloned calves born that are long-term survivors ranges between 47 and $81 \%$ (Lanza et al., 2001; Heyman et al., 2002b; D. Wells, unpublished). With adult somatic cell NT we have observed an effect of donor cell cycle stage, with significantly greater viability of G0-derived cloned calves ( $81 \%$ ) compared with G1 clones (50\%). Post-natal losses with cloned sheep are greater still with both somatic and embryonic cell clones (31 and $42 \%$ survival, respectively; Wells et al., 1998a; D. Wells, unpublished). In cattle, there was no difference in embryo survival to term with transgenic cell lines, all containing additional copies of bovine casein genes, compared with the wild type cells ( 19 and $17 \%$, respectively). However, in the transgenic group, a higher proportion of calves had died by the age of weaning $(54 \%)$ compared with cloned controls ( $32 \%$; G. Laible, P. L'Huillier and D. Wells, unpublished).

\section{Phenotypes of adult clones}

Although there are some studies indicating that clones can be physiologically normal and apparently healthy for the tests examined (Lanza et al., 2001), or at least that they require a period after birth to become physiologically normal (Chavatte-Palmer et al., 2002), there are other reports of abnormal clone-associated phenotypes that are apparent during the juvenile and adult phases of life. The incidence of these anomalies may vary according to species, genotype, sex, type of cell or specific aspects of the NT protocol. The cloned offspring syndrome is a continuum, in that lethality or abnormal phenotypes may occur at any phase of development depending upon the degree of dysregulation of key genes. Even apparently normal clones may have abnormal regulation of many genes that are too subtle to result in an obvious phenotype. Although these particular epigenetic aberrations may be minor and not a welfare issue for the animal, they may limit some practical applications of the technology because they decrease the potential uniformity of cloned livestock.

There has been much discussion of Dolly's shortened telomeres (Shiels et al., 1999) and the possibility of premature ageing and early onset of disease. Although Dolly may have developed arthritis (Adam, 2002) and at 6 years died at a relatively young age, this is not meaningful because she was an individual animal and this may have resulted from her largely indoor housing and handling. Other studies have provided contradictory evidence with regard to telomere length in clones, with reports of restoration of normal lengths in cattle (Tian et al., 2000; Betts et al., 2001) and mice (even after repeated recloning: Wakayama et al., 2000) 
and instances of extended telomere lengths (Lanza et al., 2000). Although telomeres may not be useful in determining life expectancy or long-term health, there are a number of reports that give reason for concern.

Most of the male mice cloned from immature Sertoli cells from the B6C3F1 strain died after about 500 days which is significantly earlier than normal (Ogonuki et al., 2002). The causes of death were severe pneumonia and hepatic failure. It remains to be determined whether this is a general phenomenon with clones but it has not yet been reported elsewhere in other mouse studies using different types of cell or mouse strain. The mouse model has the advantage of a shorter generation interval and biological lifespan to screen for these effects. Although it is encouraging that some studies report normal health of 4-year-old bovine clones (Lanza et al., 2001), it is too early to detect the phenotype reported in mice. Although an important issue, even if cloning were to shorten lifespan by for example $25 \%$, it may be of little significance in agriculture. For example, in commercial beef production, slaughter at target liveweight may be achieved within 2 years, or in the dairy industry the average lifespan of a cow in the herd is only 6 years; these examples are both substantially less than the biological limits for the species. However, premature ageing could affect production characteristics, such as meat quality.

Female mice cloned from cumulus cells developed an increased body weight phenotype commencing 8-10 weeks after birth (Tamashiro et al., 2000) that was directly attributable to increased adipose tissue (Tamashiro et al., 2002). The mice displayed other indicators of obesity, such as hyperinsulinaemia and hyperleptinaemia; however, they were not hyperphagic as adults. It appears that the increase in body weight may be influenced by mouse strain, as $77 \%$ of cumulus cell clones derived from the B6C3F1 strain showed the phenotype compared with only $20 \%$ in the B6D2F1 strain. Furthermore, there is no indication of this early onset obesity in mice cloned from immature Sertoli cells from the same strain (B6C3F1) (Ogonuki et al., 2002) or in livestock.

A clone phenotype noted across species is evidence of compromised immune systems, with thymic aplasia in cloned cattle (Renard et al., 1999) and lower antibody production in cloned mice (Ogonuki et al., 2002). Compromised immune systems may increase their susceptibility to infection and disease, although other workers have reported normal characterization of peripheral blood lymphocytes and normal responses to periodic infection (Lanza et al., 2001).

Assessment of animal behaviour and cognitive function are indicators of general physiological state and wellbeing. An examination of mice cloned from cumulus cells (Tamashiro et al., 2000) revealed that there was a delay of 1-2 days in the first appearance of three of ten preweaning developmental behaviours and milestones studied. However, subsequent tests on spatial learning, memory, activity level and motor skills were all comparable to those of controls (Tamashiro et al., 2000).

\section{Transgenerational effects}

It is important to monitor not only the health of the clones but also that of their subsequent progeny derived from sexual reproduction. Offspring of male and female clones in a range of species have been produced from both natural mating and assisted sexual reproduction, such as Al with a non-cloned partner. Conception, pregnancy, parturition and survival were all within normal ranges (Wakayama et al., 1998; Wells et al., 1998a; Lanza et al., 2001). More discriminatory is the mating of cloned females with cloned males. In both sheep (Fig. 2; D. Wells, unpublished) and mice (Tamashiro et al., 2002) there is no evidence of the placental abnormalities or large birthweights recorded in the clones. The fact that these phenotypes are 


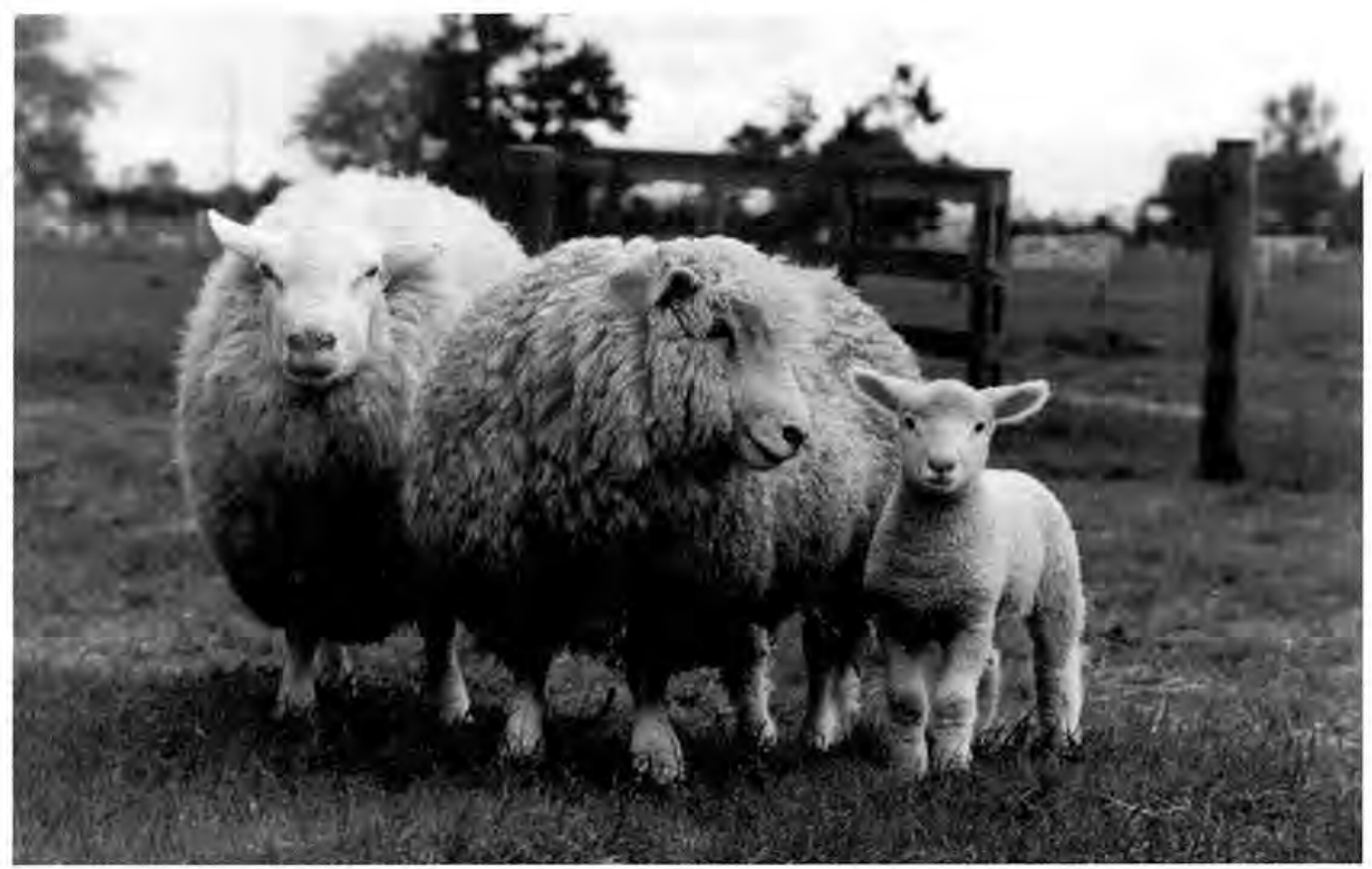

Fig. 2. Clone-associated phenotypes are not heritable in the offspring generated from sexual reproduction. The lamb in the illustration is the result of natural mating between a cloned ram (left) and a cloned ewe (centre). The lamb did not display the characteristic large birth weight, abnormal placentation or impaired kidney function phenotypes of its cloned parents. This finding indicates that the clone phenotypes were epigenetic and were repaired during gametogenesis.

not transmitted to offspring after sexual reproduction indicates that they are epigenetic and that the errors appear to be reset or corrected during gametogenesis.

It has been claimed that the obese phenotype observed in cumulus cell mouse clones is also epigenetic, as it was not heritable after mating with B6C3F1 cloned males derived from fibroblasts (Tamashiro et al., 2002). However, it has not been reported whether the males of this strain also have the obese phenotype. If the obesity is truly epigenetic, then another generation of inbreeding would be required to exclude the possibility of a recessive genetic or epigenetic trait.

\section{Livestock production characteristics, uniformity and food safety}

Few reports regarding somatic cell clones have been published to date. However, information has been provided to national regulatory agencies in a number of countries to demonstrate compositional equivalence of food products derived from cloned livestock to address safety concerns.

It would be expected with the current state of the technology that subtle epigenetic differences in somatic cell clones would increase the variation in animal performance between members of a clonal family. This variation in phenotype would be greater than that between naturally occurring monozygotic twins. Despite this, the variation in livestock production traits within a clonal family would be substantially less than the herd or population distribution depending upon the heritability of the trait (Fig. 3). 


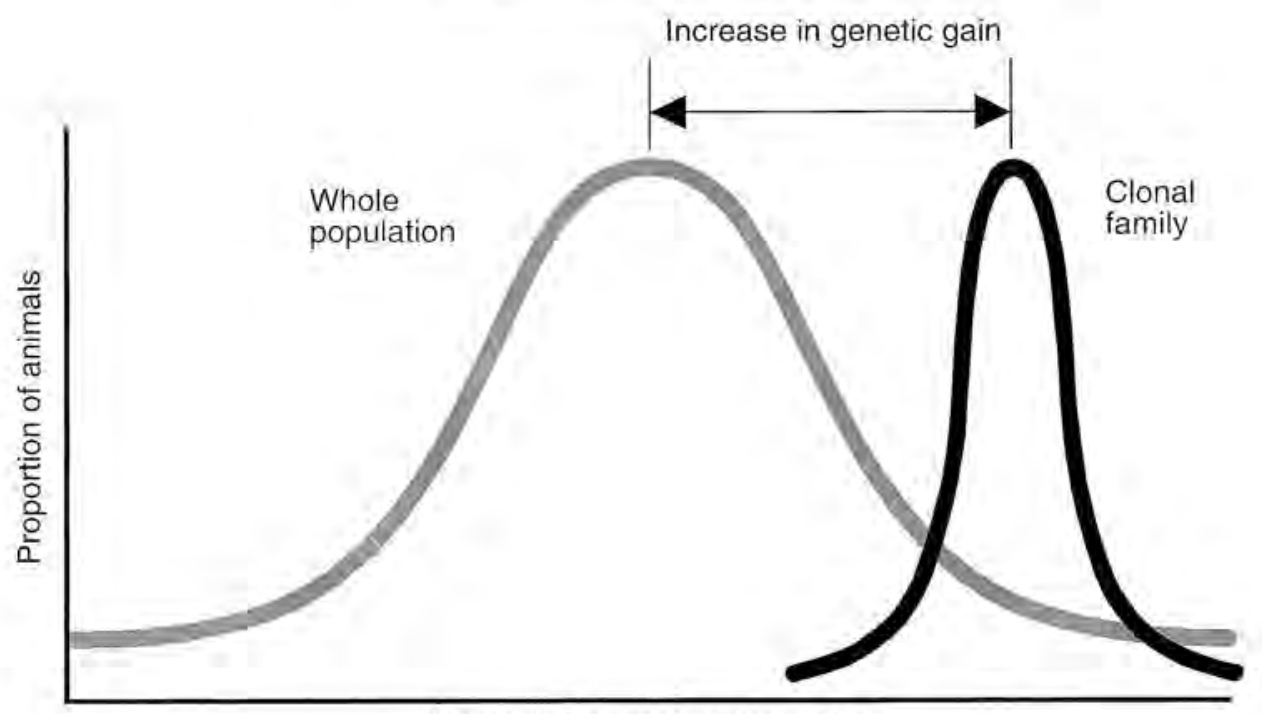

Increasing animal performance

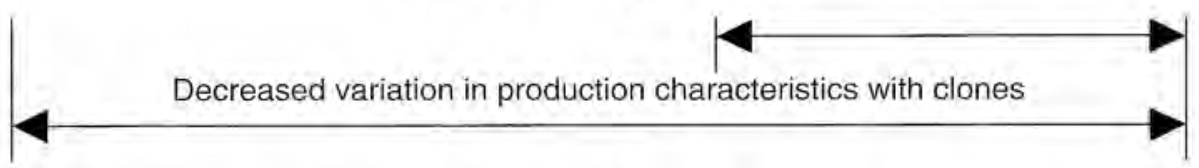

Fig. 3. The potential advantages in genetic gain and uniformity from nuclear cloning. Cloning selected genetically elite animals in the population would result in substantial increases in genetic gain from the population mean. In addition, the variability in performance characteristics among members of a clonal family would be reduced dependent upon the heritability of the trait and other epigenetic influences.

Table 1. The composition of milk from cloned cows compared with that from control cows

\begin{tabular}{lccccccc}
\hline \multicolumn{7}{c}{ Milk composition (mean \pm SD) } \\
\cline { 2 - 8 } $\begin{array}{l}\text { Type of } \\
\text { animal }\end{array}$ & $\begin{array}{c}\text { Fat } \\
(\%)\end{array}$ & $\begin{array}{c}\text { Protein } \\
(\%)\end{array}$ & $\begin{array}{c}\text { Casein } \\
(\%)\end{array}$ & $\begin{array}{c}\beta \text {-lactoglobulin } \\
(\%)\end{array}$ & $\begin{array}{c}\text { Lactose } \\
(\%)\end{array}$ & $\begin{array}{c}\text { IgG } \\
\left.(\mathrm{mg})^{-1}\right)\end{array}$ & $\mathrm{pH}$ \\
\hline $\begin{array}{l}\text { Clones } \\
(n=7)\end{array}$ & $3.49 \pm 0.24$ & $3.18 \pm 0.14$ & $2.41 \pm 0.14$ & $0.49 \pm 0.04$ & $5.09 \pm 0.11$ & $559 \pm 56$ & $6.74 \pm 0.04$ \\
$\begin{array}{l}\text { Controls } \\
(n=8)\end{array}$ & $3.98 \pm 0.72$ & $3.36 \pm 0.32$ & $2.59 \pm 0.28$ & $0.42 \pm 0.09$ & $4.82 \pm 0.26$ & $534 \pm 149$ & $6.67 \pm 0.06$ \\
\hline
\end{tabular}

At AgResearch we have had the opportunity to examine the milk composition of a set of seven cows cloned from somatic cells and derived from one donor, compared with control cows at their first lactation. The cows were managed together in one herd under typical New Zealand pastoral dairy farm conditions in the 2000-2001 season. Milk was examined throughout the entire lactation period. The data presented (Table 1) represent the average composition of some components measured and, thus, account for the seasonal changes in milk composition resulting from declining pasture quality throughout lactation. The analysis of the cloned milk, including mineral composition and individual proteins, were all within the ranges of normal milk (Table 1). In addition, the variation in milk composition was less with the clones compared with control animals. 


\section{Applications of cloning in livestock agriculture}

There are several important issues to be addressed before commercial opportunities for cloning in livestock agriculture will occur. Firstly, there are significant animal welfare concerns limiting the acceptability and utility of the technology in its current form. There needs to be confidence in the long-term health status of cloned livestock and in subsequent generations. There are issues surrounding the safety of food products derived from clones and their offspring. Regulatory agencies in a number of countries are presently addressing these aspects. The potential opportunities of cloning in agriculture are not as lucrative as in the biomedical field (from cloned-transgenics) and, in many cases, the efficiency needs to be greater and at lower cost for uptake by a large number of farmers and animal breeding companies. There needs to be ongoing assessment and modelling of the technology to identify where it best fits into different farming systems.

Some applications of cloning technology for agriculture are discussed below, and there are opportunities at different scales of production. Some of these will not be realized for some time.

\section{Rapid multiplication of desired livestock}

Cloning could enable the rapid dissemination of superior genotypes from breeding flocks and herds, directly to commercial farmers. This would substantially increase the rate of genetic gain and associated animal performance for farmers (Fig. 3). Genotypes could be provided that are ideally suited for specific product characteristics or environmental conditions. These genetic gains could be achieved through the controlled release of selected lines of elite live animals or cloned embryos. The latter would require the direct transfer of frozen-thawed cloned embryos to recipient females as an alternative to $\mathrm{Al}$. If NT is to compete with $\mathrm{Al}$ in the cattle industries it needs to be highly efficient, and have a holding pattern similar to that of $\mathrm{AI}$ or MOET. At least $50 \%$ of transferred cloned embryos must result in viable, normal offspring with minimal assistance at parturition. This is particularly important for seasonal dairy farming which demands concentrated conception and calving. Farmers could select different lines of cloned embryos to maintain genetic diversity in their herds, in much the same way as they currently select bulls for $\mathrm{Al}$. The embryo costs need to be relatively low, although a premium should be expected for high value known genetics of proven performance compared with semen from a progeny tested sire.

Cloning on a large scale would probably be best used to generate commercial animals or integrated into specialized sectors of the sire breeding herds, so as not to overly reduce the genetic variation in the breeding population. Nucleus breeding schemes will be required to produce superior dams and sires for the next generation from which the new clonal lines can be tested and selected for wider dissemination of genetic gain into the industry. However, it is conceivable that assisted sexual reproduction with female clonal families would increase the genetic variation available for subsequent selection among their progeny. Together with the storage of gametes and embryos, there is the option to cryopreserve somatic tissue as an insurance against future losses of diversity. This would be a cheaper alternative but with the same problems of deciding from which animals to preserve germplasm.

More appropriately, given the current (in)efficiencies, there is a niche opportunity in the production of small numbers of cloned, physiologically normal animals with superior genetics for breeding. These could be clones of performance tested animals, especially sires. This would be particularly relevant in the sheep and beef industries, in which cloned sires could be used in widespread natural mating to provide an effective means of disseminating their superior genetics and substitute for $\mathrm{Al}$ (which in these more extensive industries is often expensive and 
inconvenient). This opportunity is also applicable for the dairy industry, in which cloned sires could satisfy international demands for frozen semen from popular bulls.

Efficient cloning potentially allows for the rapid production of large flocks or herds enabling an economic amount of agricultural product to be generated to meet specific or changing market requirements. This relies on identifying animals that meet these criteria and then subsequent multiplication. It is possible to identify carcasses with superior meat characteristics and to clone animals either for breeding purposes, and so capture these genetics after slaughter, or to generate herds with more consistent meat production. This has been exemplified by the use of a crossbred steer after post-slaughter meat assessment to generate a set of cloned bulls for breeding (D. Wells, unpublished).

If all animals in a particular herd are genetically identical, there is the novel opportunity to produce more uniform products. However, because livestock production traits depend upon environmental influences as well, some variability in animal performance will remain, depending on the heritability of the trait. Most agricultural production traits are only about $25 \%$ heritable. Thus, $75 \%$ of the difference in phenotype comes from environmental influences, primarily feeding management in pastoral livestock farming. There would still be variation among individual animals within a clonal family, but this would be less than production differences between non-identical animals and would provide more consistent, quality products for consumers (Fig. 3). Moreover, during the process of NT, each donor cell is fused to a separate cytoplast, many with different mtDNA, which may modify some production traits (Schutz et al., 1994; Mannen et al, 1998). This modification would be in addition to subtle epigenetic differences in gene expression arising from reprogramming or other environmental influences.

Cloning could be extremely useful in multiplying outstanding $F_{1}$ crossbred animals, or composite breeds with otherwise complicated and expensive breeding strategies, to maximize the benefits of both heterosis and uniformity within the clonal family.

\section{Cloning for phenotypic evaluation and selection}

The effective use of cloning requires the accurate identification of superior livestock in the pópulation. By simply cloning an outstanding individual adult animal, the performance of the clonal family is not assured if selection is based solely on phenotype and not genotype. The ease of accurately selecting males evaluated in progeny testing schemes is greater than with females. The accuracy could be further enhanced by using cloned dams in sire proving schemes. Before large scale cloning of individuals with outstanding phenotype, it would be wise initially to clone smaller groups (perhaps 30 individuals) and evaluate the performance of these clonal families in a range of different environments to gain a more accurate measure of the true genetic superiority of each donor. This procedure would incur the delay of an extra generation, but gain from more thorough evaluation. The testing of clonal families is similar to progeny testing sires, but fewer animals are needed to give the same accuracy of selection because they are in essence genetically identical. This possibly enables greater selection pressure to be exerted by measuring more cloned families (McClintock, 1998).

Marker-assisted selection strategies to identify favourable genes that correlate with production will aid in selecting desirable genotypes in the future (Bishop et al., 1995). The rate of genetic gain would be enhanced by evaluating embryos produced from elite matings rather than adults. Clones could then be produced from cell lines established from these selected embryos. However, unless markers have exceptional predictive value, the actual phenotype of the embryo clones will remain uncertain and would need to be performance tested before larger scale release. 


\section{Animal conservation}

Cloning can be used along with other forms of assisted reproduction to help preserve indigenous breeds of livestock that have production traits and adaptability to local environments that should not be lost from the global gene pool (Wells et al., 1998b). At the very least, it is appropriate to consider the cryopreservation of somatic cells from these endangered animals as insurance against further losses in diversity.

\section{Cloning for transgenic applications}

Transgenic farm animals can be produced using donor cells that have been previously genetically modified (Schnieke et al., 1997). The advantages of the NT system compared with conventional pronuclear injection principally include: (i) the ability to introduce a specific transgene into a desired genetic background (particularly important for agricultural traits); (ii) all of the embryos and offspring are transgenic (none should be mosaic); and (iii) the generation of small herds from each cell line in the first generation, rather than individual founder animals. Although the present NT technology is able to produce a few founder transgenics, currently it is desirable to use assisted sexual reproduction thereafter to multiply animals further and to circumvent potential epigenetic aberrations in the cloned generation. The most efficient means of introducing a transgene into the wider livestock population is through Al. Ideally, the sire should be homozygous for the desired trait so all progeny receive a copy of the transgene. Animal industries may choose to introduce the transgene on a new genetic background each year using cell lines derived from the most recently selected progeny tested sires.

A disadvantage with random transgenesis is often the variable expression, dependent upon site of integration and copy number. For both better characterization of the transgenic genotype and reliability of expression, it would be preferable to introduce the transgene into a specific chromosomal site to be appropriately regulated. Although possible (McCreath et al., 2000), this is hampered by the limited lifespan in vitro and difficulty in homologous recombination in somatic cells. Additional advantages of homologous recombination include opportunities either to remove undesirable genes (Denning et al., 2001) or subtly to modify existing genes, altering the function and properties of the protein or enzyme in the desired manner.

The high value biomedical opportunities will have a minimal impact on livestock farming principally because of the relatively small number of animals involved (depending upon the quantities of product required). For agricultural transgenics, functional genomics will contribute greatly to the understanding of the genes that influence livestock production traits and provide the knowledge to modify the appropriate genes accurately to generate new and desired animal products in the future. At present, transgenic projects in New Zealand are focused on basic scientific understanding and involve evaluating the safety and economic benefits of the technology before release of the genetically modified animals to farmers and their agricultural products to the public are contemplated.

Internationally, transgenic livestock projects are aimed at increasing the quantity and quality of valuable milk, meat, wool/fibre components and improving environmental sustainability that will have economic benefits for farmers and processors, or additional health benefits for consumers (Murray et al., 1999). These aims may be achieved through altering specific genes to improve the feed conversion efficiency of livestock animals, growth rate, muscle and milk composition, or to improve disease and pest resistance resulting in improved animal welfare and reduced reliance on animal remedies. At AgResearch we have introduced additional copies of bovine $\beta$ - and $\kappa$-casein genes into female bovine fetal fibroblasts and produced NT-transgenic calves containing this genetic modification. The analysis of hormonally 
induced milk from these heifers showed substantially increased concentrations of casein protein (G. Laible, P. L'Huillier and D. Wells, unpublished). Future studies aim to evaluate the processing properties of this enhanced milk.

\section{Conclusions}

Cloning livestock after somatic cell NT involves numerous steps, each with potential for perturbing development. NT is a complex technology to implement for agricultural applications. For these reasons, initial commercialization will focus on producing small numbers of high value animals for breeding purposes, particularly cloning progeny tested sires. Until the technology is improved, these surviving clones carry an ethical cost in terms of justifying animal welfare concerns from the high rates of mortality throughout gestation and the post-natal period. More experimental data needs to be gathered on the production characteristics of clones and cloned transgenics, and their offspring, to confirm the potential opportunities and the role that nuclear transfer may play in farming systems in the 21 st century. data.

The author would like to thank colleagues at AgResearch for the inclusion of unpublished, collaborative

\section{References}

Adam D (2002) Clone pioneer calls for health tests Nature 415103

Ambrosetti DC, Scholer HR, Dailey L and Basilico C (2000) Modulation of the activity of multiple transcriptional activation domains by the DNA binding domains mediates the synergistic action of Sox2 and Oct-3 on the fibroblast growth factor-4 enhancer Journal of Biological Chemistry $27523387-23397$

Beebe D, Wheeler $M$, Zeringue $H$, Walters $E$ and Raty S (2002) Microfluidic technology for assisted reproduction Theriogenology 57 125-135

Betts D, Bordignon V, Hill J, Winger Q, Westhusin M, Smith L and King W (2001) Reprogramming of telomerase activity and rebuilding of telomere length in cloned cattle Proceedings National Academy of Sciences USA 98 1077-1082

Bishop MD, Hawkins GA and Keefer CL (1995) Use of DNA markers in animal selection Theriogenology 43 $61-70$

Boiani M, Eckardt S, Scholer HR and McLaughlin KJ (2002) Oct4 distribution and level in mouse clones: consequences for pluripotency Genes and Development 16 1209-1219

Bruggerhoff $\mathrm{K}$, Zakhartchenko $\mathrm{V}$, Wenigerkind $\mathrm{H}$ et al. (2002) Bovine somatic cell nuclear transfer using recipient oocytes recovered by ovum pick-up: effect of maternal lineage of oocyte donors Biology of Reproduction $66367-373$

Campbell KH, McWhir J, Ritchie WA and Wilmut I (1996) Sheep cloned by nuclear transfer from a cultured cell line Nature $\mathbf{3 8 0} 64-66$

Chavatte-Palmer P, Heyman Y, Richard C, Monget P, LeBourhis D, Kann G, Chilliard $Y$, Vignon $X$ and Renard JP (2002) Clinical, hormonal and hemato- logic characteristics of bovine calves derived from nuclei from somatic cells Biology of Reproduction 66 1596-1603

Chung YG, Mann MR, Bartolomei MS and Latham KE (2002) Nuclear-cytoplasmic 'tug of war' during cloning: effects of somatic cell nuclei on culture medium preferences of preimplantation cloned mouse em bryos Biology of Reproduction 66 1178-1184

Daniels R, Hall V and Trounson AO (2000) Analysis of gene transcription in bovine nuclear transfer embryos reconstructed with granulosa cell nuclei Biology of Reproduction 63 1034-1040

De Sousa PA, King T, Harkness L, Young LE, Walker SK and Wilmut I (2001) Evaluation of gestational deficiencies in cloned sheep fetuses and placentae Biology of Reproduction 65 23-30

De Sousa PA, Dobrinsky IR, Zhu J et al. (2002) Somatic cell nuclear transfer in the pig: control of pronuclear formation and integration with improved methods for activation and maintenance of pregnancy Biology of Reproduction 66 642-650

Denning C, Burl S, Ainslie A et al. (2001) Deletion of the alpha(1,3)galactosyl transferase (GGTA1) gene and the prion protein (PrP) gene in sheep Nature Biotechnology 19 559-562

Dinnyes A, Ritchie WA, Travers A, Ainslie A, Harkness L, Fletcher J, King TJ and Wilmut I (2002) Sheep somatic cell nuclear transfer: effect of the oocyte morphology and breed on embryonic and fetal development Theriogenology 57408

Eggan K, Akutsu $\mathrm{H}$, Hochedlinger K, Rideout W, 3rd, Yanagimachi R and Jaenisch R (2000) XChromosome inactivation in cloned mouse embryos Science 290 1578-1581 
Eggan K, Akutsu H, Loring I, Jackson-Grusby L, Klemm $\mathrm{M}$, Rideout WM, 3rd, Yanagimachi $\mathrm{R}$ and Jaenisch R (2001) Hybrid vigor, fetal overgrowth and viability of mice derived by nuclear cloning and tetraploid embryo complementation Proceedings $\mathrm{Na}$ lional Academy of Sciences USA $986209-6214$

Garry FB, Adams R, McCann JP and Odde KG (1996) Postnatal characteristics of calves produced by nuclear transfer cloning Theriogenology 45 141-152

Hayashida T, Eversole-Círe P, Jones PA and Sasaki H (1997) Imprinted genes are up-regulated by growth arrest in embryonic fibroblasts Joumal of Biochemistry (Tokyo) 122 901-903

Heyman Y, Chavatte-Palmer P, LeBourhis D, Camous S, Vignon $X$ and Renard JP (2002a) Frequency and oCcurrence of late-gestation losses from cattle cloned embryos Biology of Reproduction 66 6-13

Heyman $Y$, Zhou Q, Lebourhis D, Chavatte-Palmer P, Renard JP and Vignon X (2002b) Novel approaches and hurdles to somatic cloning in cattle Cloning and Stem Cells 4 47-55

Hill JR, Roussel AJ, Cibelli JB et al. (1999) Clinical and pathologic features of cloned transgenic calves and fetuses (13 case studies) Theriogenology 51 14511465

Hill JR, Burghardt RC, Jones K, Long CR, Looney CR, Shin T, Spencer TE, Thompson JA, Winger QA and Westhusin ME (2000) Evidence for placental abnormality as the major cause of mortality in firsttrimester somatic cell cloned bovine fetuses Biology of Reproduction 63 1787-1794

Hochedlinger Kand Jaenisch R (2002) Monoclonal mice generated by nuclear transfer from mature B and $T$ donor cells Nature 415 1035-1038

Humpherys D, Eggan K, Akutsu H, Hochedlinger $\mathrm{K}$, Rideout WM, 3rd, Biniszkiewicz D, Yanagimachi $R$ and Jaenisch $\mathbf{R}$ (2001) Epigenetic instability in ES cells and cloned mice Science 293 95-97

Inoue K, Kohda T, Lee J et al. (2002) Faithful expression of imprinted genes in cloned mice Science 295297

Jones KL, Hill J, Shin TY, Lui L and Westhusin M (2001) DNA hypomethylation of karyoplasts for bovine nuclear transplantation Molecular Reproduction and Development 60 208-213

Kang YK, Koo DB, Park JS, Choi YH, Chung AS, Lee KK and Han YM (2001a) Aberrant methylation of donor genome in cloned bovine embryos Nature Genetics $28 \quad 173-177$

Kang YK, Koo DB, Park JS, Choi YH, Lee KK and Han YM (2001b) Influence of oocyte nuclei on demethylation of donor genome in cloned bovine embryos FEBS Letters 499 55-58

Kang YK, Park JS, Koo DB, Choi YH, Kim SU, Lee KK and Han YM (2002) Limited demethylation leaves mosaic-type methylation states in cloned bovine preimplantation embryos EMBO Journal 21 1092-1100

Karnikova L, Horska M, Tomanek M, Kanka J, Urban F, Moor R and Fulka J, Jr (1998) Chemically enuc- leated mouse oocytes: ultrastructure and kinetics of histone $\mathrm{H} 1$ kinase activity Reproduction, Nutrilion and Development 38 643-651

Kikyo N and Wolffe AP (2000) Reprogramming nuclei: insights from cloning, nuclear transfer and heterokaryons Journal of Cell Science 113 11-20

Kirchhof N, Carnwath JW, Lemme E, Anastassiadis K, Scholer $\mathrm{H}$ and Niemann $\mathrm{H}$ (2000) Expression pattern of Oct-4 in preimplantation embryos of different species Biology of Reproduction 63 1698-1705

Kono T (1997) Nuclear transfer and reprogramming Reviews of Reproduction 2 74-80

Kruip ThAM and den Daas JHG (1997) In vitro produced and cloned embryos: effects on pregnancy, parturition and offspring Theriogenology 47 43-52

Kubota C, Yamakuchi H, Todoroki J, Mizoshita K, Tabara N, Barber M and Yang X (2000) Six cloned calves produced from adult fibroblast cells aiter long-term culture Proceedings National Academy of Sciences USA 97 990-995

Lanza RP, Cibelli JB, Blackwell C et al. (2000) Extension of cell life-span and telomere length in animals cloned from senescent somatic cells Science $\mathbf{2 8 8}$ 665-669

Lanza RP, Cibelli JB, Faber D, Sweeney RW, Henderson B, Nevala W, West MD and Wettstein P) (2001) Cloned cattle can be healthy and normal Science 294 1893-1894

McClintock AE (1998) Impact of cloning on cattle breeding systems Reproduction, Fertility and Development $10667-669$

McCreath KJ, Howcroft J, Campbell KH, Colman A, Schnieke AE and Kind AJ (2000) Production of genetargeted sheep by nuclear transter from cultured somatic cells Nature 405 1066-1069

Machaty Z and Prather RS (1998) Strategies for aclivating nuclear transfer oocytes Reproduction, Fertility and Development 10 599-613

Mannen H, Kojima T, Oyama K, Mukai F, Ishida T and Tsuji S (1998) Effect of mitochondrial DNA variation on carcass traits of Japanese Black cattle Journal of Anima/ Science 76 36-41

Murray ID, Anderson GB, Oberbauer AM and McGloughlin MM (1999) In Transgenic Animals in Agriculture pp 290. CABI Publishing, Oxon, UK

Niemann $H$, Wrenzycki $C$, Lucas-Hahn A, Brambrink T, Kues WA and Carnwath JW (2002) Gene expression patterns in bovine in vitro-produced and nuclear transier-derived embryos and their implications for early development Cloning and Stem Cells $429-$ 38

Niwa H, Miyazaki J and Smith AG (2000) Quantitative expression of Oct-3/4 defines differentiation, dedifferentiation or self-renewal of ES cells Nature Genetics 24 372-376

Oback B and Wells D (2002) Donor cells for nuclear cloning - many are called but few are chosen Cloning and Stem Cells 4 147-168 
Ogonuki N, Inoue K, Yamamoto Y et al. (2002) Early death of mice cloned from somatic cells Nature Genetics 30 253-254

Ohgane J, Wakayama T, Kogo Y, Senda S, Hattori N, Tanaka S, Yanagimachi R and Shiota K (2001) DNA methylation variation in cloned mice Gienesis 30 45-50

Onishi A, Iwamoto M, Akita T, Mikawa S, Takeda K, Awata T, Hanada $\mathrm{H}$ and Perry AC (2000) Pig cloning by microinjection of fetal fibroblast nuclei Science 289 1188-1190

Ono Y, Shimozawa N, Ito M and Kono T (2001) Cloned mice from fetal fibroblast cells arrested at metaphase by a serial nuclear transfer Biology of Reproduction $6444-50$

Ozil JP and Huneau D (2001) Activation of rabbit oocytes: the impact of the $\mathrm{Ca}^{2+}$ signal regime on development Development 128 917,-928

Peura T, Lewis IM and Trounson AO (1998) The effect of recipient oocyte volume on nuclear transfer in cattle Molecular Reproduction and Development $50185-191$

Peura TT, Lane MW, Lewis IM and Trounson AO (2001) Development of bovine embryo-derived clones after increasing rounds of nuclear recycling Molecular Reproduction and Development $58 \quad 384$ 389

Polejaeva IA, Chen SH, Vaught TD et al. (2000) Cloned pigs produced by nuclear transfer from adult somatic cells Nature 407 86-90

Prather RS, Barnes FL, Sims MM, Robl JM, Eyestone WH and First NL (1987) Nuclear transplantation in the bovine embryo: assessment of donor nuclei and recipient oocyte Biology of Reproduction 37859 866

Prather RS, Sims MM and First NL (1989) Nuclear transplantation in early pig embryos Biology of Reproduction $41414-418$

Reik W, Romer I, Barton SC, Surani MA, Howlett SK and Klose J (1993) Adult phenotype in the mouse can be affected by epigenetic events in the early embryo Development 119 933-942

Renard JP, Chastant S, Chesne P, Richard C, Marchal J, Cordonnier N, Chavatte P and Vignon X (1999) Lymphoid hypoplasia and somatic cloning Lancet 353 1489-1491

Renard JP, Zhou Q, LeBourhis D, Chavalte-Palmer P, Hue I, Heyman Y and Vignon X (2002) Nuclear transfer technologies: between successes and doubts Theriogenology 57 203-222

Rideout WM, 3rd, Wakayama T, Wutz A, Eggan K, Jackson-Grusby L, Dausman J, Yanagimachi R and Jaenisch R (2000) Generation of mice from wild type and targeted ES cells by nuclear cloning Nature Genetics 24 109-110

Rideout WM, 3rd, Eggan K and Jaenisch R (2001) Nuclear cloning and epigenetic reprogramming of the genome Science 293 1093-1098
Roemer I, Reik W, Dean W and Klose J (1997) Epigenetic inheritance in the mouse Current Biology 7 $277-280$

Schnieke AE, Kind AJ, Ritchie WA, Mycock K, Scott AR, Ritchie M, Wilmut I, Colman A and Campbell KH (1997) Human factor IX transgenic sheep produced by transfer of nuclei from transfected fetal fibroblasts Science $2782130-2133$

Schutz MM, Freeman AE, Lindberg GL, Koehler CM and Beitz DC (1994) The effect of mitochondrial DNA on milk production and health of dairy cattle Livestock Production Science 37 283-295

Shiels PG, Kind AJ, Campbell KH, Waddington D, Wilmut I, Colman A and Schnieke AE (1999) Analysis of telomere lengths in cloned sheep Nature 399 $316-317$

Steinborn R, Schinogl P, Zakhartchenko V, Achmann R, Schernthaner W, Stojkovic M, Wolf E, Muller M and Brem G (2000) Mitochondrial DNA heteroplasmy in cloned cattle produced by fetal and adult cell cloning Nature Genetics 25 255-257

Tamashiro KL, Wakayama T, Blanchard RJ, Blanchard DC and Yanagimachi R (2000) Postnatal growth and behavioral development of mice cloned from adult cumulus cells Biology of Reproduction 63 328334

Tamashiro KL, Wakayama T, Akutsu H ef al. (2002) Cloned mice have an obese phenotype not transmitted to their offspring. Nature Medicine 8262-267

Tatham BG, Dowsing AT and Trounson AO (1995) Enucleation by centrifugation of in vitro-matured bovine oocytes for use in nuclear transfer Biology of Reproduction 53 1088-1094

Thompson JG, Gardner DK, Pugh PA, McMillan WH and Tervit HR (1995) Lamb birth weight is affected by culture system utilized during in vitro pre-elongation development of ovine embryos Biology of Reproduction 53 1385-1391

Thompson JG, McNaughton C, Gasparrini B, McGowan LT and Tervit HR (2000) Effect of inhibitors and uncouplers of oxidative phosphorylation during compaction and blastulation of bovine embryos cultured in vitro. Journal of Reproduction and Fertility 118 $47-55$

Tian XC, Xu J and Yang X (2000) Nomal telomere lengths found in cloned cattle Nature Genetics 26 $272-273$

Vajta G, Lewis IM, Hyttel P, Thouas GA and Trounson AO (2001) Somatic cell cloning without micromanipulators Cloning 3 89-95

Wakayama T and Yanagimachi R (2001a) Mouse cloning with nucleus donor cells of different age and type Molecular Reproduction and Development $58376-$ 383

Wakayama T and Yanagimachi R (2007b) Effect of cytokinesis inhibitors, DMSO and the timing of oocyte activation on mouse cloning using cumulus cell nuclei Reproduction 122 49-60 
Wakayama I, Perry AC, Zuccotti M, Johnson KR and Yanagimachi R (1998) Full-term development of mice from enucleated oocytes injected with cumulus cell nuclei Nature 394 369-37.4

Wakayama T, Rodriguez I, Perry AC, Yanagimachi R and Mombaerts P (1999) Mice cloned from embryonic stem cells Proceedings National Academy of Sciences USA $9614984-14989$

Wakayama T, Shinkai Y, Tamashiro KL et al. (2000) Cloning of mice to six generations Nature 407 318-319

Wells DN, Thompson JGE, Tervit HR, James RW and Udy GB (1990) Experiences in the application of embryo bisection in sheep MOET programmes The Proceedings of the New Zealand Society of Animal Production $50431-435$

Wells DN, Misica PM, Day AM and Tervit HR (1997) Production of cloned lambs from an established embryonic cell line: a comparison between in vivo-and in vitro-matured cytoplasts Biology of Reproduction $57385-393$

Wells DN, Misica PM, Day AM, Peterson AJ and Tervit HR (1998a) Cloning sheep from cultured embryonic cells Reproduction, Fertility and Development $\mathbf{1 0}$ 615-626

Wells DN, Misica PM, Tervit HR and Vivanco $W H$ (1998b) Adult somatic cell nuclear transfer is used to preserve the last surviving cow of the Enderby Island cattle breed Reproduction, Fertility and Development $10369-378$

Wells DN, Misica PM and Tervit HR (1999) Production of cloned calves following nuclear transfer with cultured adult mural granulosa cells Biology of Reproduction 60 996-1005

Willadsen SM (1986) Nuclear transplantation in sheep embryos Nature 320 63-65

Wilmut I, Schnieke AE, McWhir I, Kind AJ and Campbell KH (1997) Viable offspring derived from fetal and adult mammalian cells Nature 385810 813

Wilson IM, Williams JD, Bondioli KR, Looney CR, Westhusin ME and McCalla DF (1995) Comparison of birth weight and growth characteristics of bovine calves produced by nuclear transfer (cloning), embryo transfer and natural mating Animal Reproduction Science 38 73-83

Wrenzycki C, Wells D, Herrmann D, Miller A, Oliver J, Tervit R and Niemann H (2001) Nuclear transfer protocol affects messenger RNA expression patterns in cloned bovine blastocysts Biology of Reproduclion $65309-317$

Xue F, Tian XC, Du F, Kubota C, Taneja M, Dinnyes A, Dai Y, Levine H, Pereira LV and Yang X (2002) Aberrant patterns of $\mathrm{X}$ chromosome inactivation in bovine clones Nature Genetics 31 216-220

Yamazaki $Y$, Makino $H$, Hamaguchi-Hamada $K$, Hamada S, Sugino H, Kawase E, Miyata T, Ogawa M, Yanagimachi R and Yagi T (2001) Assessment of the developmental totipotency of neural cells in the cerebral cortex of mouse embryo by nuclear transfer Proceedings National Academy of Sciences USA 98 $14022-14026$

Young LE, Sinclair KD and Wilmut I (1998) Large offspring syndrome in cattle and sheep Reviews of Reproduction 3 155-163

Young LE, Fernandes K, McEvoy TG, Butterwith SC, Gutierrez CG, Carolan C, Broadbent PJ, Robinson IJ, Wilmut I and Sinclair KD (2001) Epigenetic change in IGF2R is associated with fetal overgrowth after sheep embryo culture Nature Genetics 27 153-154

Zou X, Chen Y, Wang Y et al. (2001) Production of cloned goats from enucleated oocytes injected with cumulus cell nuclei or fused with cumulus cells Cloning 3 31-37 